\title{
Biofilm formation in total hip arthroplasty: prevention and
}

\section{treatment.}

Elena García-Gareta ${ }^{\mathrm{a}, *}$, Christopher Davidson ${ }^{\mathrm{b}}$, Alexandra Levin ${ }^{\mathrm{a}}$, Melanie J Coathup ${ }^{\mathrm{b}}$, Gordon W Blunn ${ }^{\mathrm{b}}$.

aRAFT Institute of Plastic Surgery, Mount Vernon Hospital, Northwood HA6 2RN, UK.

bJohn Scales Centre for Biomedical Engineering, Institute of Orthopaedics and Musculoskeletal Science, Division of Surgery and Interventional Science, University College London, Royal National Orthopaedic Hospital, Stanmore HA7 4LP, UK.

*Corresponding author:

Dr Elena García-Gareta

RAFT

Leopold Muller Building

Mount Vernon Hospital

Northwood HA6 2RN

United Kingdom

Tel: +44 1923844555

Fax: +44 1923844031

garciae@raft.ac.uk 


\begin{abstract}
Biomaterial science is a very active area of research, which has allowed the successful use of implants in the orthopaedic field for over a century. However, implant infection remains a clinical concern as it is associated with extensive patient morbidity and a high economic burden, which is predicted to increase due to an ageing population. Bacteria are able to adhere, colonise and develop into biofilms on the surface of biomaterials making associated infections physiologically different to other post-surgical infections. Unfortunately, biofilms exert increased protection from the host immune defence system and an increased resistance to antibiotic therapy in comparison to their planktonic counterparts. The aim of this review paper is to assess the current knowledge on treatments, pathogenesis and the prevention of infections associated with orthopaedic implants, with a focus on total hip arthroplasty.
\end{abstract}




\section{Introduction}

Biomaterials have been extensively used as orthopaedic implants for over a century. The early 1900s saw the first successful application through use of metallic bone plates for fixation of long bone fractures ${ }^{1}$. Since then, prosthetic implants or catheters for example, have become commonplace in medical practice. Biomaterial science has made dramatic improvements in the structural design, functionality and biocompatibility of implants however, infection continues to be a significant clinical complication.

When Sir John Charnley developed the low-friction hip arthroplasty in the UK during the early 1960s he was aware of the risk of infection and recognised its importance by introducing antibiotics such as gentamycin into the bone cement; developed an enclosure that isolated the operating theatre from the rest of the room into which filtered air could be passed the so called "Charnley tent" and developed a full-body gown that incorporated an exhaust system ${ }^{2}$. In 1969, John Charnley reported an infection rate of $9.5 \%$ following total hip arthroplasty (THA $)^{3}$. In comparison, contemporary reports of infection in THA vary between 1 to $2 \%{ }^{4}$. This large fall in the rate of infection is due to a number of factors: improved patient selection, laminar airflow operating rooms, protocols of perioperative antibiotic prophylaxis and an improved generic understanding of the importance of sterilisation ${ }^{5}$. Despite the fall in the rate of infection in the last decades, acquisition of infection is still a clinical concern associated with extensive patient morbidity and a high economic burden. Infection has been identified as the most common cause of failure of revision THA, which have steadily increased in recent years and are forecast to substantially grown over the next decades as the number of primary THA increases due to an ageing population $^{6}$.

Infections associated with orthopaedic implants are physiologically different to other post-surgical infections due to the physical presence of the biomaterial itself. Bacterial cells are able to adhere, colonise and develop into biofilms on the implant surface. A biofilm consists of a cluster of bacterial cells embedded and surrounded within their own extracellular matrix $(\mathrm{ECM})^{7-9}$. Biofilms protect bacteria from the host immune defence (HID) system and also increase bacterial resistance to antibiotic therapy when compared to their planktonic counterparts $^{8-10}$. The aim of this review paper is to assess current knowledge on treatments, pathogenesis and prevention of infections associated with implants used in total hip arthroplasty. 


\section{Classification of infection and treatment}

Infection may be classified as early, delayed or late. Early infections, which appear within 3 months of surgery, are predominantly a result of perioperative inoculation of highly virulent microorganisms during the surgical procedure or following 2 to 4 days prior to complete wound healing. Delayed infections appear between 3 and 24 months post-surgery. They are also primarily associated with perioperative bacterial inoculation although they are generally caused by less virulent microorganisms, thus the longer latency time prior to establishment of the infection. Late infections, after 24 months post-surgery, are more commonly associated with contiguous and haematogenous acquisition from remote foci of infection. The most frequent foci for late infections are skin, respiratory, dental and urinary infections ${ }^{11,12}$. However, as perioperative antibiotics have been shown to reduce the rate of acquisition of late infections, surgical inoculation must contribute in $\operatorname{part}^{13}$.

The long-term use of antibiotics for periprosthetic joint infections (PJI) as a suppressive therapy was advocated for approximately 2 decades ${ }^{14}$. The landmark study by Goulet et al. in 1988 yielded the most successful results to date: at a mean of 4 years post-surgical intervention for THA, the prostheses were reported as having remained in place with good functionality in $63 \%$ of the patients selected for the study ${ }^{15}$. Patients selected for the suppressive therapy were those who refused operative treatment, were unfit for surgical intervention, had bacterial infections sensitive to multiple antibiotics, had a deep wound infection within 2 months of the primary THA or any combination of these factors ${ }^{15}$. Suppressive therapy has clear benefits namely low patient morbidity and economic burden associated with treatment. However, bacterial evolution is surpassing that of antibiotic development and consequently the armoury of antibiotics at the disposal of clinicians is becoming limited against increasingly resistant bacterial strains. The emergence of resistant microorganisms, coupled with the innate ability of biofilms to evade the HID system, means that antibiotic suppressive therapy alone is no longer effective as a suppressive treatment for PJIs ${ }^{16}$. Therefore, surgical intervention is currently the only definitive treatment for PJIs.

Regardless of the chosen surgical intervention, operative debridement and perioperative antibiotic therapy are mainstays of treatment protocol. The extent of parenteral antibiotic therapy varies within the literature but generally spans between 4 and 6 weeks ${ }^{17-19}$. A paper by McDonald and colleagues reported on a retrospective cohort study of revision patients at the Mayo Clinic compared the reinfection rates of patients receiving less than 4 weeks of parenteral antibiotic therapy with those receiving equal to or greater than 4 weeks ${ }^{17} .43 \%$ patients in 
the former group compared to only $8 \%$ patients in the latter group developed a recurrent infection ${ }^{17}$. A report by Garvin et al. investigated 40 patients who underwent unilateral revision surgery each administered with 6 weeks of intravenous antibiotics. Results showed that only 2 of the 40 hips (5\%) developed recurrent infection at an average follow-up of 5 years ${ }^{19}$. Apart from antibiotic therapy and operative debridement, the most appropriate surgical intervention must be selected based on strict patient criteria: retention of the prosthesis, re-implantation either by a one or two-staged process, permanent resection arthroplasty or amputation (Table 1$)^{20-23}$. For the majority of patients re-implantation is the intervention performed as either a one-stage, direct, or two-stage exchange procedure ${ }^{22}$, which is considered the "gold standard" as it is thought to yield the lowest re-infection rates $^{24}$.

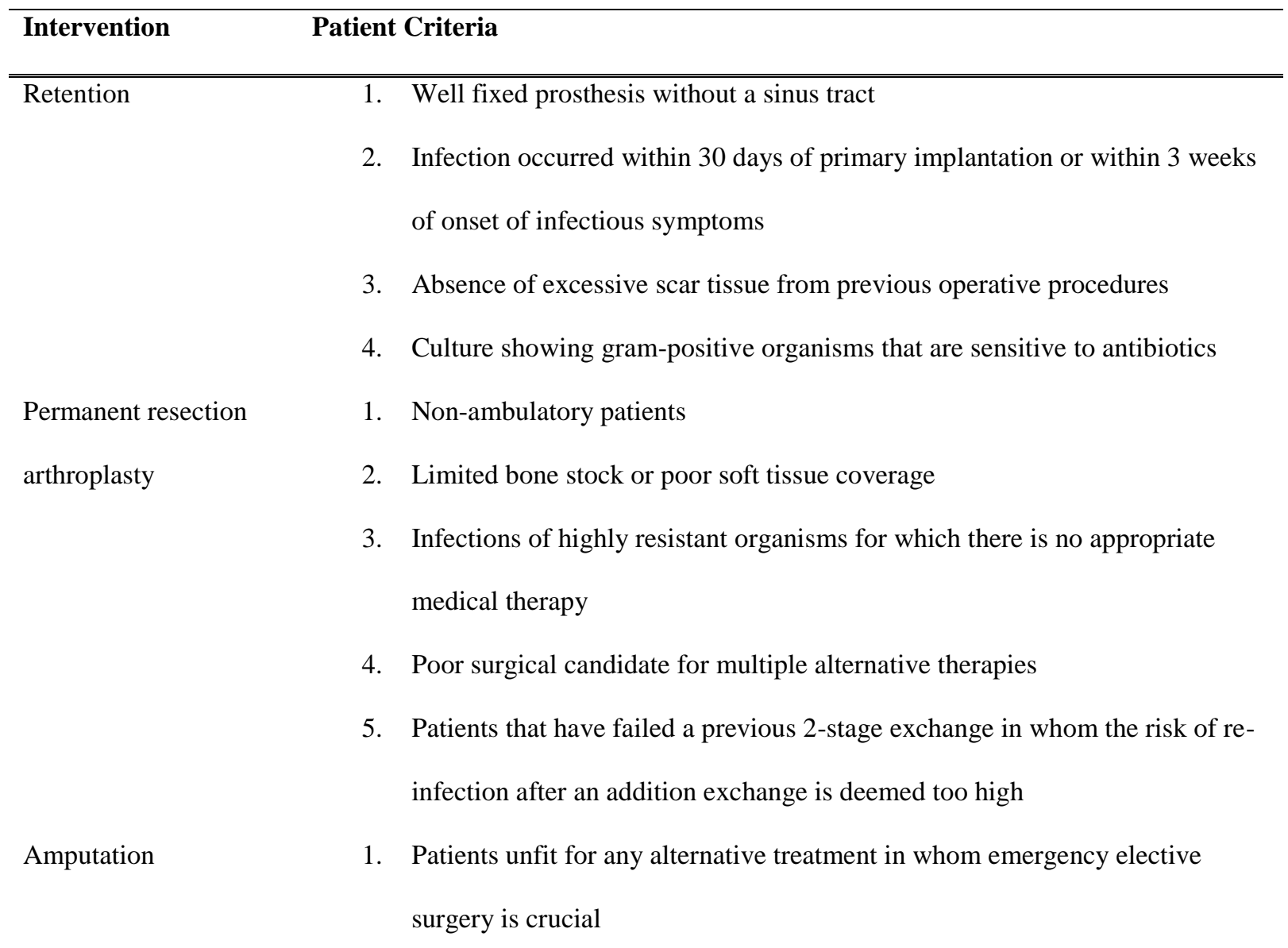

Table 1: Patient criteria for retention, permanent resection arthroplasty and amputation interventions for total hip arthroplasty complicated by infection ${ }^{21-23}$. 
However, assessment of results identified from the literature revealed one core problem with the current treatment: it is based on an abundance of poorly constructed, small sample sized studies, the majority of which represent short- or mid-term Level IV evidence (case series). Dramatic variation in case series inclusion criteria, such as extent of antibiotic treatment, and underlying patient demographics, make any comparison between series futile. No randomised controlled trials have yet been performed comparing the 2 interventions. Two systematic published reviews, which compiled the longitudinal studies and case series, each according to different inclusion criteria, found no significant difference in reinfection rates, reported at approximately $10 \%$, between one- and two-stage procedures ${ }^{25,26}$. Although eradication of infection does represent an important endpoint, success of treatment must incorporate a balance between overall risk and achieved outcome. A Markov expected-utility decision analysis, taking into account factors other than the pure outcome of reinfection rates, found the direct exchange procedure to be superior to the two-stage procedure in terms of overall Quality Adjusted Life Years delivered to patients ${ }^{27}$. Nevertheless, there is an urgent need for a well designed, multicentre, randomised controlled trial comparing the two interventional treatments.

\section{Economic analysis of total hip arthroplasty complicated by infection}

Although several small-scale analyses have contributed to this research area, to date, no formal comprehensive economic analysis exists for THA complicated by infection in the UK. According to the National Joint Registry 620,400 primary THA procedures have been performed between 2003 and $2013^{28}$. Of the reported cases, 14,903 (2.4\%) implants have been revised, with 2,072 (13.9\%) of these revisions accountable to infection. It is important to take into account that the reported infection rates are likely under-estimates, as many cases of presumed aseptic failure are in fact accountable to misdiagnosed infection ${ }^{29}$. The revision rate varies depending on the type of total hip replacement: a retrospective cohort study Kandala et al. recently analysed 239,000 patient records from April 2003 to March 2012 held by the National Joint Registry for England and Wales and found that 10 year revision rate estimates were highest for uncemented prostheses with ceramic-on-ceramic bearing surfaces (3.93-4.33\%, depending on the analytical method used) while cemented prostheses with ceramic-on-polyethylene bearing surfaces had the lowest revision rates (1.88-2.11\% depending on the analytical method used $)^{30}$. 
The acquisition of a PJI incurs a number of additional costs to health service providers including preoperative evaluation, revision procedure, increased length of post-operative stay (LPS), and any required additional physiotherapy. It has been estimated that the increase in the LPS for patients receiving treatment for THA complicated by infection compared to those receiving a primary THA is 11.5 days, costing $£ 3,342^{31}$. When extrapolated to all cases of revision in the UK recorded in the National Joint Registry, this adds up to 23,828 days of hospitalisation and an economic burden of almost $£ 7,000,000$.

Klouche and colleagues assessed the economic implication of infected THA in France ${ }^{32}$. Whilst direct costs are not comparable to those in other countries, relative increases in costs between primary THA and revision procedures are relevant. The group reported an increased LPS, 24 versus 6 days, and an increased rate of transfer to hospital for post-operative care and physiotherapy, 65\% versus 55\%, for revision versus primary THA procedures respectively. The relative increase in total cost of the revision procedure and associated treatment was found to be 3.3 times higher than that of a primary THA ${ }^{32}$.

Ultimately, there is a clear inadequacy of current treatment with regards to the degree of patient morbidity, the economic burden it imposes on the National Health System (NHS), the high re-infection rates associated with revision procedures and the poor quality evidence that current treatment is based upon. A rapid rise in PJI rates is expected in the foreseeable future. This is due to better diagnostic techniques, a growing number of implanted prostheses in an aging population and an increased prosthetic residency time ${ }^{33}$. It is expected that by $203523 \%$ of the total UK population will be over 65 , a $6 \%$ increase from $2010^{34}$. In the US, it was estimated that total hip replacements would grow by $174 \%$ from currently over 300,000 annually to 572,000 by 2030 , with total hip revision projected to grow by $137 \%{ }^{35,36}$. Similar percentages could be expected for the UK.

While current management of infected THA has been effective, its application is finite, and focus must be put on prevention rather than treatment before the expected exponential rise in PJIs surpasses NHS resources and becomes an unaffordable economic burden for the UK.

\section{Pathogenesis of infections associated with implants}

The space between the biomaterial and the surrounding local tissues, the interstitial milieu, is characterised as a locus minus resistentiae, which literally means "place of less resistance", and is often referred to as an immuno- 
incompetent fibro-inflammatory zone. This phenomenon has been demonstrated by several experimental models where the presence of foreign material within a surgical site allows the establishment of infection at significantly lower microbial critical doses ${ }^{37}$. The impaired HID allows for surface colonisation by microbes of lower virulence potential, giving rise to an environment for opportunistic infection ${ }^{38}$. Thus, the higher infection rates associated with biomaterials when compared to common surgical site infections is explained by the increased susceptibility to infection in the presence of a biomaterial ${ }^{39}$. In addition to the impaired HID, certain biomaterials and/or superficial coatings can physically, chemically and biologically support and enhance microbial growth ${ }^{40-44}$. Coatings and biomaterial surfaces often incorporate superficial pores in order to encourage ingrowth of host tissue into the implant thus mediating successful integration ${ }^{45,46}$. Unfortunately, these pores constitute superficial niches that physically protect microbes from phagocytic cells. Bio-resorbable biomaterials can locally dissipate nutrients over time that may be used by bacteria to support their own growth and proliferation ${ }^{40-43}$. Moreover, metallic ions released from certain metals, comprised within biomaterials and coatings, have been shown to chemically enhance microbial function by altering internal metabolic processes for several microbial species ${ }^{44}$. The incidence of infection in patients who are immunocompromised rises. For example patients receiving chemotherapy after removal of a bone tumour show increased levels of infection, which may be as high as $11 \%{ }^{47}$. This may also be associated with the longer operative time and poor soft tissue coverage but nevertheless the immunological health of the patient is important. Recent reports on the incidence of infection in metal on metal hip replacements suggest that infection may be higher than with more conventional hip replacements and this has been attributed to a combination of particulate debris, molecular effects of $\mathrm{Co}$ and $\mathrm{Cr}$ ions on soft tissues, and/or products of corrosion that may change the local environment predisposing to infection ${ }^{48,49}$.

As mentioned earlier, the presence of the biomaterial itself, which provides a surface that serves as anchorage for microbes and subsequent biofilm formation, constitutes the problem with regards to establishment of infection ${ }^{50}$. Bacteria involved in biofilm formation show increased protection from the HID system as well as an enhanced therapeutic resistance ${ }^{10}$. Therefore, adherent bacteria in biofilms are significantly harder to eradicate through the use of antibiotics in comparison to their planktonic counterparts, thus the need for surgical removal of a substantial proportion of infected implants ${ }^{16}$. 


\subsection{Biofilm formation}

Understanding biofilm development is mandatory for a critical analysis of strategies aimed at eradicating or preventing biofilm formation. Distinct stages in the biofilm formation process can be identified (Table 2).

\begin{tabular}{|c|c|c|}
\hline Stage & Mechanisms & Function \\
\hline $\begin{array}{l}\text {-Host ECM proteins (i.e. collagen } \\
\text { fibrinogen, fibronectin, elastin) } \\
\text { colonise the biomaterial surface. }\end{array}$ & $\begin{array}{l}\text {-Vroman effect: serum proteins with the } \\
\text { highest motility arrive first at the } \\
\text { biomaterial surface and subsequently } \\
\text { absorb onto it, but are later replaced by } \\
\text { proteins with less motility and higher } \\
\text { affinity for the biomaterial surface. } \\
\text {-Attachment of host cells from local tissue } \\
\text { and secretion of ECM. }\end{array}$ & $\begin{array}{l}\text {-Pre-conditioning of the } \\
\text { biomaterial surface. }\end{array}$ \\
\hline $\begin{array}{l}\text {-Attachment of bacteria to the host } \\
\text { ECM proteins. }\end{array}$ & $\begin{array}{l}\text {-Expression of adhesins which mediate cell } \\
\text { anchorage and fixation. }\end{array}$ & $\begin{array}{l}\text {-Formation of bacterial } \\
\text { micro-colonies on the } \\
\text { biomaterial surface. }\end{array}$ \\
\hline $\begin{array}{l}\text {-Production of an extracellular } \\
\text { polymeric biofilm matrix that } \\
\text { encapsulates the cells. }\end{array}$ & $\begin{array}{l}\text {-Bacterial cells secrete eDNA, lipids, } \\
\text { exopolysaccharides and extracellular } \\
\text { proteins with amyloid (insoluble fibrous } \\
\text { protein aggregates) properties able to } \\
\text { polymerise into higher-order structures. } \\
\text {-Different biofilm components have } \\
\text { different functions: bacteria-host cells } \\
\text { interaction, protection, adhesion. }\end{array}$ & $\begin{array}{l}\text {-Provide protection and a } \\
\text { means of evading the host } \\
\text { immune response. }\end{array}$ \\
\hline $\begin{array}{l}\text {-The biofilm reaches its critical } \\
\text { capacity and is disrupted, releasing } \\
\text { excess bacteria from the matrix that } \\
\text { either pass to adjacent areas of un- } \\
\text { colonised biomaterial surface or into } \\
\text { the bulk fluid as planktonic bacterial } \\
\text { cells. }\end{array}$ & $\begin{array}{l}\text {-Not understood yet. } \\
\text {-In staphylococci, Quorum sensing (control } \\
\text { of gene expression in a cell-density } \\
\text { dependent manner) and surfactant peptides } \\
\text { structure biofilms both in vitro and in vivo } \\
\text { and lead to biofilm detachment. }\end{array}$ & -Propagation of infection. \\
\hline
\end{tabular}

Table 2: Summary of mechanisms and functions of the different stages involved in biofilm formation ${ }^{51-80}$. 
Before biofilm formation, host ECM proteins colonise the biomaterial surface, a phenomenon that is principally governed by the Vroman effect, where the highest motility serum proteins arrive first and adsorb onto the biomaterial surface, being later replaced by less motile serum proteins with higher affinity for the biomaterial surface $^{51,52}$. In addition to the Vroman effect, host cells from the local tissue attach to the biomaterial surface and start depositing an ECM. The host ECM contains proteins such as collagen, fibrinogen, fibronectin or elastin, to which bacterial cells adhere through the expression of adhesins, which mediate cell anchorage and fixation $^{53}$. Several of these active adhesive mechanisms are regarded as critical virulence factors and are frequently considered for characterisation of clinical isolates in studies of molecular pathogenesis. Bacterial strains that do not produce an ECM are comparatively less adhesive. Therefore, they are less likely to cause a chronic implant infection ${ }^{54}$. A study by Davies and Geesey showed that bacterial transcription factors associated with ECM production, such as those coding for alginate biosynthesis, are activated and up-regulated in response to attachment to a solid surface ${ }^{55}$. Thus, it can be concluded that is the bacterial attachment itself that initiates the subsequent stages in the biofilm formation and maturation process.

Attached bacteria proliferate and form micro-colonies. Initial attachment to the surface of an implant is important and can differ between different bacteria. A surface colonised by Staphylococcus aureus is "decorated" with proteins that are covalently anchored to the cell wall peptidoglycan. Structural and functional analysis has identified four distinct classes of surface proteins, of which microbial surface component recognizing adhesive matrix molecules (MSCRAMMs) are the largest class. These surface proteins have numerous functions, including adhesion to and invasion of host cells and tissues, evasion of immune responses and biofilm formation. Thus, cell wall-anchored proteins are essential virulence factors for the survival of $S$. aureus in the commensal state ${ }^{56}$. Pseudomonas aeruginosa expresses a mucoid exopolysaccharide matrix with alginate as a major component, lipopolysaccharide (LPS) $)^{57,58}$ and the filamentous surface appendages flagella and pili ${ }^{59,60}$. Several of these surface-associated structures are known to function as adherence factors or adhesins.

The hallmark of biofilm formation is the production of an extracellular polymeric biofilm matrix that encapsulates the bacterial cells providing protection and a means of evading the host immune response $\mathrm{s}^{8,9,61}$. The fact that bacterial cells can secrete extracellular material that helps with attachment was reported by Claude Zobell and Esther Allen as early as in 1935: "The film of bacteria may promote the attachment of macroscopic 
organisms in different ways. They may form a mucilaginous surface to which the fouling organisms in the planktonic or free-swimming stage readily adhere until they can prepare their own holdfast" ${ }^{\prime 62}$. Today we know that the extracellular biofilm matrix produced by the majority of microorganisms is not just a slime surrounding the cells but a highly ordered structure where protein localization is extensively observed across the matrix as well as interactions between components. The biofilm matrix is composed of extracellular DNA (eDNA), lipids, exopolysaccharides and extracellular proteins of which many have amyloid-like properties and can polymerize into higher-order structures ${ }^{63-65}$.

The production of the extracellular biofilm matrix establishes the success of biofilm communities by protecting the bacterial cells against phagocytosis, antibiotics and high fluid flow conditions ${ }^{66}$. Several strategies are adopted by different microbial species and therefore various compositions are encountered. Some bacteria synthesize protein fibres to form a scaffold with structural integrity and rigidity so cells and other matrix components like exopolysaccharides can attach to $i^{67-69}$. The function of some matrix components is to facilitate the interaction between bacterial and host cells, such as the curli fibres produced by E. coli cells. Apart from its structural function, curli fibres are needed by $E$. coli cells to attach to various protein components of the host cells at the onset of infection ${ }^{70-72}$. A protective function is seen for other matrix components: the cellulose present in E. coli biofilms increases the resistance of the bacterial community to desiccation while the selfassembling bacterial hydrophobin BslA forms a highly hydrophobic coat over the Bacillus subtilis biofilm shielding it from aqueous environments ${ }^{73-75}$. An adhesive function is seen for the polysaccharide intercellular adhesin (PIA) secreted by staphylococci during biofilm maturation ${ }^{76}$.

Eventually, an established biofilm matrix will reach its critical capacity and get disrupted. At this point excess bacteria are released from the biofilm matrix to pass either to adjacent areas of un-colonised biomaterial surface, thus propagating the biofilm, or into the bulk fluid as planktonic bacterial cells ${ }^{65,77}$. Although in recent years investigation of biofilm disruptive processes has been intensified, so far we lack understanding of the forces and molecular determinants behind the detachment of cells when critical capacity is reached. Understanding these mechanisms is of key importance.

It has been shown that bacteria concentrated in a biofilm release small auto-inducer molecules that lead to quorum sensing that is able to regulate gene expression. Quorum sensing bacteria produce and release chemical 
signal molecules that increase in concentration as a function of cell density ${ }^{76}$. The detection of a minimal stimulatory concentration of an auto-inducer above a threshold leads to an alteration in gene expression. Recent studies indicate that quorum sensing may play a key role in biofilm structuring and detachment, like the phenolsoluble modulins, which are surfactant peptides secreted by staphylococci (S. aureus and S. epidermidis are the most frequent pathogenic species among orthopaedic clinical isolates of implant associated infections) in a quorum-sensing controlled fashion, which have been found to structure biofilms both in vitro and in vivo and lead to biofilm detachment ${ }^{76,78,79}$. However, more research in this exciting area is needed to prevent propagation of the biofilm as well as systemic infection.

Finally, it is important to mention that some bacterial species like Pseudomonas aeruginosa display multiple phenotypes during development of the biofilm with five stages of biofilm development that includes: (i) reversible attachment, (ii) irreversible attachment, (iii) maturation-1, (iv) maturation-2, and (v) dispersion. The maturation-1 stage is characterised by layered cells in clusters, with a cluster thickness of less than $10 \mu \mathrm{m}$. The maturation-2 stage is characterized as a point where there is maximum cell cluster development, with cluster thickness up to $100 \mu \mathrm{m}$ and where the majority of cells are displaced from the substratum. When planktonic cells were compared with maturation-2 stage biofilm cells, more than 800 proteins were shown to have a sixfold or greater change in expression level ${ }^{80}$.

\subsection{Resistive mechanisms of biofilms}

Bacteria within biofilms show higher levels of resistance to antibiotics than their planktonic counterparts ${ }^{81}$. One investigated mechanism is the incomplete penetration of antibiotics through the full depth of the multi-layered biofilm matrix, which prevents full eradication of the microbes ${ }^{82-87}$. Mathematical models have shown that, for the majority of antibiotic compounds, no generic barrier to penetration should exist within a biofilm ${ }^{88}$. However, numerous in vitro studies have demonstrated the failure of antibiotics to fully penetrate the biofilm. In 1994 Suci and colleagues used attenuated total reflection Fourier transform infrared spectroscopy to monitor transport of the fluoroquinolone antibiotic ciprofloxacin to the Pseudomonas aeruginosa biofilm-germanium substratum interface, which was significantly impeded by the biofilm ${ }^{82}$. Earlier in 1992 Hoyle and co-workers demonstrated similar results with the antibiotic piperacillin and its diffusion through a dialysis membrane colonised by Pseudomonas aeruginosa ${ }^{83}$. Several studies have shown that polymeric compounds such as the anionic polysaccharide alginate exist within the biofilm matrix and that such compounds impede the diffusion of 
antibiotics through the matrix ${ }^{84-87}$. A proposed explanation is ionic trapping, whereby the anionic polymeric compounds such as alginate attract and stagnate cationic antibiotics such as aminoglycosides. It is also well established that the viscoelastic properties of the biofilm, determined by its matrix composition, influence antimicrobial penetration ${ }^{89}$. In contrast to these findings, the successful diffusion of rifampicin and vancomycin through a Staphylococcus epidermidis biofilm produced via a comparable method was shown by Dunne and colleagues in 1993. However, sterilisation of the biofilm was not accomplished after $72 \mathrm{~h}$ of antibiotic treatment ${ }^{87}$.

Studies like the ones discussed in the previous paragraph have undoubtedly shown that the biofilm matrix retards antibiotic penetration through the biofilm. However, the extent of impedance varies significantly between studies and is dependent on both the antibiotic, bacterial type and matrix constituents ${ }^{83,87,90}$. Consequently inadequate penetration cannot fully account for the resistive phenomenon, and it may be presumed that other mechanisms are concurrently involved.

Heterogeneity exists within biofilms in three forms: spatial heterogeneity, heterogeneity of response, and heterogeneity of cells. Several studies have shown that these concepts of heterogeneity within a biofilm constitute an important survival strategy, allowing evasion of antibiotic therapy and persistence of infection ${ }^{91-98}$. Spatial heterogeneity is the distribution of regions of high and low cell growth rate within a biofilm, and was identified by Wentland and colleagues in $1996^{91}$. Depletion of bacterial nutritive compounds or the accumulation of inhibitory metabolites within these regions may explain the quiescent or non-growing state of the bacterial cells ${ }^{92}$. Since the mechanism of action of many antimicrobial agents such as penicillin, which targets cell wall synthesis, is dependent on bacteria existing in a growing state, these regions of slow-growth may explain the inefficiency of many antibiotics to fully eradicate biofilms ${ }^{93}$. Other studies have also observed gradients of physiological activity in response to antibiotic treatment, indicating that the response to antibiotics within a biofilm is non-uniform thus contributing to the likelihood of survival of portions of the biofilm. Huang et al. grew biofilms of Klebsiella pneumonia and Pseudomonas aeruginosa on stainless steel surfaces in continuous-flow annular reactors and treated them with $2 \mathrm{mg} / \mathrm{ml}$ of the biocide monochloramine for $2 \mathrm{~h}^{94}$. Results revealed gradients of respiratory activity within biofilms in response to monochloramine treatment: cells near the biofilm-bulk fluid interface lost respiratory activity first while greater respiratory activity persisted deep in the biofilm. Korber and co-workers also showed that cells located in closest proximity to the biofilm-bulk fluid 
interface within an established Pseudomonas fluorescens biofilm experienced cell elongation when subjected to the fluoroquinolone fleroxacin ${ }^{95}$. The last phenomenon of heterogeneity refers to the polymicrobial community of biofilms. The coexistence of bacterial kingdoms has been shown to provide a competitive advantage, with altered sensitivities to antimicrobial agents observed as a result of mutually beneficial relationships established within biofilms ${ }^{96-98}$. Among orthopaedic clinical isolates of implant-associated infections staphylococci ( $S$. aureus and S. epidermidis) account for approximately $65 \%$ of the pathogenic species found, others being from the genus Pseudomonas (8\%), Enterococcus (5\%), Escherichia (2\%) or Sptreptococcus (2\%) ${ }^{99}$.

Several other theories underlying the resistive phenomenon have been put forward, including numerous other environmental impacts on antibiotic efficacy ${ }^{100-103}$, formation of a dormant, protected, spore-like phenotype in response to growth on a surface ${ }^{104,105}$, and amplification of transcription factors coding for antibiotic resistive traits $^{106}$.

Regarding environmental features of biofilms that contribute to the inefficacy of antibiotics, de Beer and colleagues demonstrated through the use of miniature electrodes that oxygen can be completely consumed at superficial zones of biofilms and therefore, deep zones will consequently contain anaerobic niches ${ }^{100}$. Several antibiotics, including aminoglycosides, have been to shown to be significantly less active and subsequently less effective in anaerobic than in aerobic states against the same bacterium ${ }^{102}$. A study by Zhang et al. demonstrated that a difference in local $\mathrm{pH}>1$ between the bulk fluid and biofilm interior as a result of acidic waste product accumulation can directly antagonise antibiotic action ${ }^{101}$. Finally, Prigent-Combaret and co-workers showed that bacteria within biofilms encounter higher-osmolarity conditions, greater oxygen limitation, and higher cell density than in the liquid phase ${ }^{103}$. It has been theorised that the stress response due to these environmental features may induce a change in the relative concentration of porins in the cell envelope thereby reducing the bacterial cells antibiotic permeability and thus the effectiveness of the antibiotic treatment.

A more speculative theory proposes that the resistance observed within biofilms is due to a small subpopulation of cells from a dormant, protected, spore-like phenotype in response to growth on a surface, as opposed to nutrient limitation ${ }^{104}$. The fact that planktonic cells that are derived from biofilms are in most cases fully susceptible to antibiotics ${ }^{104}$ seems to support this theory. Moreover, newly formed biofilms are too thin to form 
physical barriers to antibiotic penetration or metabolite accumulation and consequently the resistance still observed must be accountable elsewhere, possibly supporting this alternative hypothesis ${ }^{105}$.

The final resistive mechanism associated with biofilms is the rapid transfer of genetic transcription factors. Generically, gene transfer through plasmid conjugation is an important mechanism of genetic trait transfer. However, diverse complex environments such as those observed in biofilms represent an ideal niche for augmentation of this phenomenon. Quantitative in situ analysis has shown higher conjugation frequencies for sessile bacteria, such as those within biofilms, than their planktonic counterparts ${ }^{106}$. Microbial biofilms therefore epitomise an idyllic environment for amplification of both naturally occurring and induced antibiotic resistive traits.

Understanding the various mechanisms discussed in this review paper by which bacteria in biofilms have increased resistance to antibiotics, summarised in Table 3, is critical to develop new strategies to prevent biofilm formation on the surface of orthopaedic implants. 


\begin{tabular}{|c|c|c|}
\hline Resistive mechanism & Evidence & References \\
\hline $\begin{array}{l}\text {-Incomplete penetration of } \\
\text { antibiotics through the full } \\
\text { depth of the multi-layered } \\
\text { biofilm matrix. }\end{array}$ & $\begin{array}{l}\text {-Numerous in vitro studies have demonstrated the failure of } \\
\text { antibiotics to fully penetrate the biofilm. } \\
\text {-Several studies have shown that polymeric compounds exist } \\
\text { within the biofilm matrix, i.e. alginate, which impede the } \\
\text { diffusion of antibiotics through the matrix (perhaps through } \\
\text { ionic trapping). } \\
\text {-Viscoelastic properties of the biofilm, determined by its } \\
\text { matrix composition, influence antimicrobial penetration. }\end{array}$ & "-82-89 \\
\hline $\begin{array}{l}\text {-Heterogeneity: spatial, } \\
\text { response and cellular. }\end{array}$ & $\begin{array}{l}\text {-Spatial heterogeneity: regions of high and low cell growth } \\
\text { rate within a biofilm have been identified. } \\
\text {-Heterogeneity of response: gradients of physiological activity } \\
\text { in response to antibiotic treatment identified. } \\
\text {-Cellular heterogeneity: coexistence of different bacterial } \\
\text { species provides competitive advantage, with altered } \\
\text { sensitivities to antimicrobial agents observed as a result of } \\
\text { mutually beneficial relationships established within biofilms. }\end{array}$ & $-91-98$ \\
\hline $\begin{array}{l}\text {-Environmental features of } \\
\text { biofilms. }\end{array}$ & $\begin{array}{l}\text {-Deep zones of the biofilm contain anaerobic niches as oxygen } \\
\text { can be completely consumed at superficial zones. } \\
\text {-Difference in local } \mathrm{pH}>1 \text { between the bulk fluid and biofilm } \\
\text { interior as a result of acidic waste product accumulation } \\
\text { demonstrated. } \\
\text {-Altered internal osmotic environment due to metabolite } \\
\text { accumulation. }\end{array}$ & $-100-103$ \\
\hline $\begin{array}{l}\text {-Presence of a small sub- } \\
\text { population of cells from a } \\
\text { dormant, protected, spore- } \\
\text { like phenotype. }\end{array}$ & $\begin{array}{l}\text {-Planktonic cells derived from biofilms are, in most cases, } \\
\text { fully susceptible to antibiotics. } \\
\text {-Newly formed biofilms are too thin to form a physical barrier } \\
\text { to antibiotic penetration or metabolite accumulation. }\end{array}$ & $-104,105$ \\
\hline $\begin{array}{l}\text {-Rapid transfer of genetic } \\
\text { transcription factors. }\end{array}$ & $\begin{array}{l}\text {-Diverse complex environments, such as biofilms, augment } \\
\text { the phenomenon of gene transfer through plasmid } \\
\text { conjugation. } \\
\text {-Quantitative in situ analysis has shown higher conjugation } \\
\text { frequencies for sessile bacteria than for their planktonic } \\
\text { counterparts. }\end{array}$ & -106 \\
\hline
\end{tabular}

Table 3: Summary of resistive mechanisms of biofilms to antibiotics. 


\section{Preventing biofilm formation: principles and methods}

Due to the multiple mechanisms underlying biofilm resistance discussed in the previous section (4.2) preventing or treating PJI is not a simple task. In order to be clinically effective any single method must overcome multiple resistive mechanisms. The interstitial milieu represents the forefront of the battle between host and bacterial cells $^{99}$. The aim of prevention is to deter adhesion and subsequent colonisation of the implant surface by bacteria, instead allowing osseointegration of host tissue with the implant. This competitive phenomenon is known as the 'race for colonisation' ${ }^{\prime 07}$. Colonisation of the implant surface by local host cells mediates the establishment of a tissue seal, preventing bacterial adhesion and subsequent establishment of infection ${ }^{108}$.

Bactericidal activity of a preventative therapy must reach a therapeutic threshold whereby adjacent bacterial cells are eradicated. However, excessive bactericidal activity may have cytotoxic effects on local host tissue cells and prevent successful implant-tissue integration. Host tissue-implant integration is imperative to achieve implant stability and reduce the risk of aseptic loosening ${ }^{46}$. Pin tract infection for external fixation of frames is very often associated with relative movement of the pin in the bone and it is believed that this increases bacterial colonisation of the implant surface. A required balance is evident: prevention must exert sufficient bactericidal toxicity as to prevent implant failure as a result of septic loosening, but not be excessively cytotoxic as to prevent osseointegration and aseptic loosening.

Conventional systemic antibiotics administered perioperatively still represent the main prophylactic strategy against infection. However, due to the phenomenon of multi-drug resistance associated with biofilms, this strategy fails to completely eradicate $\mathrm{PJIs}^{109}$. Additionally, perioperative antibiotics serve no prophylactic function against late infection acquired via the haematogenous route ${ }^{109}$. The majority of new methods are designed to complement systemic antibiotic therapy and focus on 1) local delivery of antimicrobial substrates from the implant or cavity filling material; 2) preventing the attachment of bacterial onto the implant surface; and 3) methods to remove the bacteria from the implant surface making then susceptible to antibiotic therapy in their planktonic state. With local delivery, the critical concentration of the bactericidal agent resides directly at the implant-soft tissue interface, allowing higher antimicrobial doses to be achieved with lesser risk of systemic toxicity and subsequent renal or hepatic complications ${ }^{110}$. 


\subsection{Internal methods}

Internal methods are those directly associated with the implant surface or bulk material ${ }^{65,111}$. The use of a bioactive bulk material that is intrinsically antimicrobial for implant production would be ideal. Unfortunately, few materials that express such antimicrobial properties are sufficiently biocompatible. Additionally, this is further complicated by the need for the material to ideally match the mechanical properties of natural bone in order to minimise stress shielding or risk of implant fracture. Therefore, modification of the implant surface seems the obvious path to follow. Several strategies are under research for implant surface modification: alteration of surface nano-topography, generation of an anti-adhesive surface, and superficial surface coatings. Although the three strategies will be discussed, in this review we will mainly focus on superficial surface coatings due to the abundance of research exploring this strategy.

\subsubsection{Alteration of surface nano-topography}

Alteration of surface nano-topography has been shown to affect the degree of bacterial adhesion, with irregular surfaces shown to permit a greater level of bacterial adhesion than smooth, regular ones ${ }^{112}$. In a recent comparative study, Koseki et al. evaluated the ability of the main pathogen present in implant-related infections, Staphylococcus epidermis, to form biofilms on materials with surfaces with a similar degree of smoothness: oxidised zirconium-niobium alloy, cobalt-chromium-molybdenum alloy (Co-Cr-Mo), titanium alloy (TiAl6V4), commercially available pure titanium and stainless steel. After culturing the pathogen on the different surfaces for 2-4 h the biofilm coverage rate was similar for all the materials. However, after $6 \mathrm{~h}$ the biofilm coverage rate for Co-Cr-Mo was significantly lower $(\mathrm{p}<0.05)$ than for TiAl6V4, pure titanium and stainless steel. The authors concluded that surface properties like the hydrophobicity or low surface free energy of Co-Cr-Mo may influence the two-dimensional expansion of Staphylococcus epidermis biofilms on surfaces with similar nanotopographies $^{113}$.

The fundamental flaw with nano-topographical manipulation is that bacterial adhesion to smooth surfaces still transpires, albeit to a lesser extent than irregular counterparts, and consequently it is unlikely that alteration of surface topography alone will prove sufficient as a preventative method. 


\subsubsection{Generation of an anti-adhesive surface}

Conditioning implant surfaces with antifouling agents, creating adhesion resistant surfaces is another proposed strategy. Hyaluronic acid, an anionic non-sulfated glycosaminoglycan widely found in connective, epithelial and neural ECM, has been shown to greatly reduce bacterial cell surface fractional coverage when coupled with biomaterial surfaces both in vitro and in vivo ${ }^{114}$. Since the underlying mechanism is mediated through water molecule interaction, rather than directly with bacterial cells, the same anti-adhesive effects are exerted on local host tissue cells. If osseointegration is not achieved then risk of aseptic loosening is increased, limiting the use of hydrophilic surfactants and compounds. Other studies have investigated surfaces which have a high hydrophobicity. For example diamond-like carbon surfaces doped with nitrogen or silicon show reduced Pseudomonas aeruginosa adhesion ${ }^{115}$.

\subsubsection{Superficial surface coatings}

Currently the most successful strategy primarily focuses on superficial surface coatings ${ }^{116}$. Generally coatings are made of either an intrinsically antimicrobial bulk material or a material infused with antimicrobial compounds. Chitosan, a natural polysaccharide, is an example of the former. Investigated as a biomaterial due to its biocompatibility, biodegradability, bioactivity, osteoconductivity, enhanced wound healing and innate antimicrobial properties, chitosan appears ideal for mediating tissue-implant integration and preventing biofilm formation ${ }^{117-119}$. However, studies have demonstrated inadequate bonding strength of chitosan with the implant surface ${ }^{120}$, increasing the risk of coating delamination and thus limiting its use. Nevertheless, the good biomaterial properties of chitosan may be exploited using a different approach: Li and colleagues chemically functionalised titanium-based bone implants with nano-particle-stabilised chitosan and methotrexate, a synthetic compound that interferes with cell growth and is used to treat certain types of cancer and auto-immune conditions, for inhibiting both osteoclastoma formation and biofilm formation ${ }^{121}$.

The majority of antimicrobial compounds investigated for use in orthopaedic coatings have proven bactericidal activity, such as common topical disinfectants or systemic antibiotics. Examples of topical disinfectants include silver sulfadiazine and chlorhexidine, and especially certain metals such as copper $(\mathrm{Cu})$, zinc $(\mathrm{Zn})$, magnesium $(\mathrm{Mg})$ or particularly silver $(\mathrm{Ag})$. 
A randomised controlled trial compared the efficacy of silver sulfadiazine and chlorhexidine in swine models for infection rate reduction ${ }^{122}$. Bacterial cell adhesion was significantly lower on biomaterials coated with the antimicrobial compounds when compared to controls. Additionally, no biofilm formation, or local or systemic toxicity, was noted in intervention groups ${ }^{122}$.

$\mathrm{Cu}$ has demonstrated bactericidal properties whilst human cells demonstrate relatively low sensitivities to $\mathrm{Cu}^{123}$. Nevertheless, the mechanism of "contact killing" of bacteria by $\mathrm{Cu}$ surfaces is still poorly understood. Particularly, the influences of bacteria-metal interaction, media composition, and $\mathrm{Cu}$ surface chemistry on contact killing require further investigation. In a study by Hans and colleagues, copper oxide formation on $\mathrm{Cu}$ during standard antimicrobial testing was measured in situ using spectroscopic ellipsometry. The authors found that $\mathrm{CuO}$ significantly inhibited contact killing compared to pure $\mathrm{Cu}$. Conversely, thermally generated $\mathrm{Cu}_{2} \mathrm{O}$ was essentially as effective in contact killing as pure copper. The authors concluded that since it is $\mathrm{Cu}_{2} \mathrm{O}$ that primarily forms on $\mathrm{Cu}$ under ambient conditions, antimicrobial objects would retain their antimicrobial properties even after oxide $\left(\mathrm{Cu}_{2} \mathrm{O}\right)$ formation ${ }^{124}$. $\mathrm{Cu}$ presents disadvantages though, as studies have shown that $\mathrm{Cu}$ incorporation within hydroxyapatite coatings does not deter biofilm formation, whilst other metals such as silver (Ag) have shown to exert bactericidal activity ${ }^{125}$. Cu has also been shown to form large fibrous capsules in vivo after 28 and 56 days of sub-cutaneous implantation in rats ${ }^{126}$, which could potentially contribute to an increased risk of aseptic loosening. However, Hoene and co-workers carried out a study aimed at evaluating a $\mathrm{Cu}$ coating produced by galvanic deposition on TiAl6V4 plates in terms of in vivo $\mathrm{Cu}$ release and local inflammatory reactions for $72 \mathrm{~h}$ after intramuscular implantation in rats. Results showed that $\mathrm{Cu}$ coated TiAl6V4 implants had antibacterial effectiveness in vitro, measurable $\mathrm{Cu}$ amounts were released in vivo and caused a moderate local inflammatory response ${ }^{127}$, thus suggesting that fine-tuning of $\mathrm{Cu}$ coatings on orthopaedic materials could be effective in fighting biofilm formation.

Very recently Grenho and colleagues reported the antibacterial activity and biocompatibility of threedimensional and interconnected porous granules of nano-structured hydroxyapatite incorporated with different amounts of zinc oxide $(\mathrm{ZnO})$ nano-particles produced using a simple polymer sponge replication method ${ }^{128}$. The composite granules were especially effective at reducing bacterial activity in vitro and in vivo when containing a weight percentage of $2 \% \mathrm{ZnO}$, with low cell growth inhibition in vitro and no differences in the connective tissue growth and inflammatory response after subcutaneous implantation in rats ${ }^{128}$. These results suggest a 
promising potential for this composite material for prevention of biofilm formation in vivo. Similarly, the antibacterial properties of pure $(99.9 \%) \mathrm{Mg}$ in vitro and in an in vivo rat model of implant-associated methicillin-resistant Staphylococcus aureus infection was recently shown ${ }^{129}$.

The concept of exploiting metals against microorganisms is not novel. In fact, Ag was commonly used in ancient history to prevent water contamination. It is the most extensively studied metal for the purpose of fighting infection and food preservation. Unlike $\mathrm{Cu}$, the mechanism of action of $\mathrm{Ag}$ is well known and it is mediated through $\mathrm{Ag}^{+}$ions, which strongly inhibit growth through suppression of respiratory enzymes, electron transport components, and through interference with DNA functions ${ }^{130}$. The success of silver is well documented in applications such as wound dressings, burn creams, sutures and catheters ${ }^{131-136}$.

Several studies have assessed the antimicrobial efficacy of silver ions $\left(\mathrm{Ag}^{+}\right)$and $\mathrm{Ag}$ nano-particles against biofilm formation and advocate its use in prevention of biofilm-related infections ${ }^{137-141}$. The antibacterial effect of Ag nano-particles has been reported to be both size and shape dependent. However, a study by Actis and colleagues aimed at evaluating the effect of three different shapes (spherical, triangular and cuboidal) of $\mathrm{Ag}$ nano-particles on microbial susceptibility (S. aureus and methicillin-resistant S. aureus) and bone cell viability revealed that the shape of Ag nano-particles did not affect microbiota susceptibility or human fetal osteoblasts viability ${ }^{141}$. High concentrations of $\mathrm{Ag}$ nano-particles $(0.5 \mathrm{nM})$ granted significant bacterial susceptibility and significantly reduced human fetal osteoblasts viability ${ }^{141}$. In fact, human fetal osteoblasts had increasingly reduced viability to lower Ag nano-particle concentrations with an increase in exposure time ${ }^{141}$. Ag has also been used to dope hybrid coatings as reported by Tran and colleagues: hybrid coatings of titanium dioxide and polydimethylsiloxane (PDMS) were synthesised to regulate the release of Ag. The coatings, with different titanium dioxide:PDMS ratios, were deposited on discs of polyether ether ketone (PEEK) and selected ratios were shown to control Ag release and completely inhibit biofilm formation ${ }^{142}$.

One approach which is currently used in clinical practice is to coat the implant surface with Ag. It has long been known that silver is a powerful antibacterial agent: Ag-coated materials have been shown to influence bacterial adhesion, and Ag-coated prostheses have been fabricated for clinical testing where they have achieved some good results ${ }^{143,144}$. The antibacterial effects of Ag result from the release of its ions from the implant surface and the subsequent thiol bonding to the active site of many metabolic enzymes. Silver has been used in combination 
with calcium phosphate/hydroxyapatite coatings and ceramics ${ }^{145}$. Although effective, there is concern that the Ag layer may influence the metabolic status of adherent cells as well as the metallurgical properties of the implant in vivo. There is also concern that when the Ag release is complete, the implant surface will no longer function as a microbicidal agent. However, as most of the infections are associated with the operation then a limited release over a matter of weeks is warranted. Although rare, there is also the problem of Ag resistance and hypersensitivity to $\mathrm{Ag}^{+146}$. A new approach where $\mathrm{Ag}$ is incorporated into the anodised surface of titanium has shown to reduce implant related infections by around 50\%. In a case-control Wafa et al. showed the overall post-operative infection rate of the Ag-coated group of massive implants used to treat bone tumour implants was $11.8 \%$ compared with $22.4 \%$ for the control ${ }^{147}$.

In addition to its proven efficacy against biofilms, $\mathrm{Ag}$ overcomes many of the shortcomings of previously discussed prevention methods. Silver is non-toxic to human cells at small concentrations whilst highly toxic to bacterial cells, allowing the exertion of bactericidal activity with minimal cytotoxic effects ${ }^{148}$. Furthermore, development of microbial resistance against $\mathrm{Ag}^{+}$is significantly less likely, compared to commonly used antibiotics, due to the broad range of mechanisms through which it acts, unlike antibiotics which commonly act through a single mode only ${ }^{130}$. Finally, many of the production methods of silver infusion are cost-effective, i.e. immersion in silver nitrate $\left(\mathrm{AgNO}_{3}\right)$. Regardless, it is the long-term potential to prevent exposure of patients to such debilitating revision procedures and the NHS to such economic burden that is the most desirable trait that this preventative method has to offer.

Finally, antibiotics infused within coatings have been extensively researched. An approach has been to covalently attach antibiotics such as vancomycin onto the surface of titanium, which has been shown to provide a long-lived anti-bacterial layer that should be active over the lifetime of the implant. Once tethered, the antibiotic provides a constant level of protection, which might discourage colonization. Because the total amount of the agent is small compared to the quantities used for controlled release, it may be less likely to foster resistance $^{149}$. Once formed, these surfaces exhibit antibacterial activity and specificity without development of resistance. When implanted into infected femoral medullary canals in rats, it blocks bacterial proliferation and osteolysis ${ }^{150}$. The antimicrobial efficacy of antibiotic infused HA coatings has been demonstrated with multiple antibiotics, such as gentamicin, vancomycin, tobramycin and more recently rifampicin ${ }^{151-153}$. Certain antibiotics have been shown to bind poorly to calcium within calcium-phosphate coatings; consequently antibiotic release 
is too rapid and fails to provide prophylactic protection ${ }^{151}$. This limits the variety of antibiotics that can be used, potentially problematic against multi-resistant strains. Therefore, other antibiotic-infused coatings are being investigated, such as lipid-based (purified phosphatidylcholine) materials on titanium and stainless steel ${ }^{154}$ or titania nanotubes loaded inside with poly(lactide-co-glycolide) and chitosan on titanium ${ }^{155}$. The appropriateness of using antibiotics during an era of developing resistance is controversial. Several authors have raised concern that prolonged low-level antibiotic release may contribute to selection of antibiotic resistant bacterial strains, exacerbating the resistance phenomenon discussed in previous sections. Incorporation of "last resort antibiotics", used to treat severe multi-resistant bacterial strains, has been advised against.

\subsection{External methods}

External methods refer to those that are not related directly to the implant. Antibiotic impregnated cement is becoming increasingly used, especially in revision cases associated with higher re-infection rates. It has been shown to express a biphasic release pattern: an initial high concentration burst release followed by a prolonged, sub-therapeutic level of release. Success of antibiotic impregnated cement has been shown ${ }^{156}$. However, several concerns exist with its use. Firstly, conflicting evidence regarding the effect of antibiotic impregnation on mechanical properties of cement exists ${ }^{157,158}$. Secondly, there is concern regarding the sub-therapeutic level of antibiotic release and its contribution to the phenomenon of antibiotic resistance. Finally, its use is limited in uncemented procedures. An alternative could be using Ag instead of antibiotics. A recently published paper by Slane et al. studied the mechanical, material and antimicrobial properties of acrylic bone cement impregnated with Ag nano-particles showing that cements modified with Ag nano-particles significantly reduced S. aureus and S. epidermis biofilm formation on the surface of the cement while demonstrating mechanical and material properties similar to those of the non-impregnated cement ${ }^{159}$.

For uncemented procedures local delivery of gentamicin from resorbable viscous hydrogels of poly $(\mathrm{N}$ isopropylacrylamide-co-dimethyl- $\gamma$-butyrolactone acrylate-co-Jeffamine ${ }^{\circledR} \mathrm{M}-1000$ acrylamide), which delivered the antibiotic with low systemic exposure, has been proposed ${ }^{160}$. Along this line, polymeric carriers have been developed to optimise the release and targeting of antibiotics ${ }^{161}$. A different approach has been reported by Bezuidenhout and co-workers: the release of vancomycin through polyethersulfone membranes from channels in cementless TiAl6V4 cubes, thus proposing the novel approach of refillable implants to control biofilm 
formation ${ }^{162}$. Of course, one may argue whether this approach should be considered an external or internal method, or perhaps a hybrid between the two.

In addition to innovative device technologies, another approach to preventing PJI is through immunization. Although a decade ago a universal group B Sreptococcus vaccine was identified by multiple genome screen $^{163}$, an effective vaccine against $S$. aureus remains elusive, and several clinical trials have failed ${ }^{164}$. The limited success in these studies may have been the result of not accounting for the temporal variability in antigen expression and bacterial growth within a biofilm which may have hidden antigenic sites. However, given the remarkable heterogeneity of the single-species and polymicrobial infections evident in an approach that concentrates on single antigens, targeting multiple antigens may be required. A vaccine composed of four biofilm-upregulated antigens plus antibiotic administration (used to clear planktonic populations) was able to prevent biofilm infection where vaccination or antibiotic therapy alone failed. Subsequently, the protective efficacy of the $S$. aureus vaccine has been developed to include gene products with upregulated production in biofilms as well as those upregulated in the planktonic mode of growth ${ }^{165}$. Immunization strategies to prevent and treat PJI remains an important area of investigation.

Finally, the transfer of electrical current onto implanted prostheses has also been considered as a minimally invasive treatment ${ }^{166}$. However, this is also in the developing stages.

As a summary, Figure 1 depicts the different strategies discussed in this review to deter biofilm formation on the surface of implants. 


\section{Methods of Deterring Biofilm Formation}
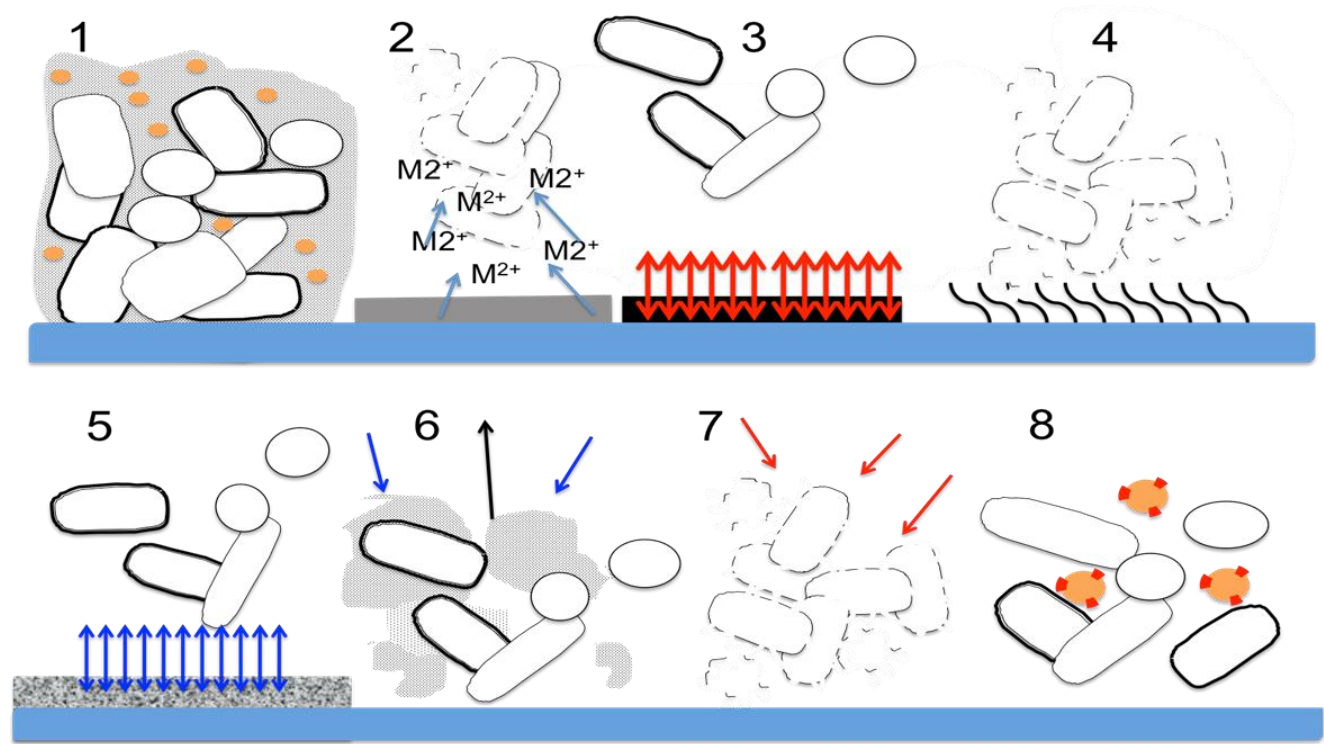

1. Multiple species biofilm producing glycocalyx with quorum sensing on the surface of the implant.

2. Release of bactericidal agents from superficial surface coatings such as metal ions $(\mathrm{Ag}, \mathrm{Cu}, \mathrm{Zn}, \mathrm{Mg})$.

3. Generation of an anti-adhesive implant surface.

4. Implant surfaces coated with antibiotics.

5. Nano-topographical implant surfaces that deter attachment.

6. Agents that prevent or destroy the formation of glycocalyx.

7. Vaccine to biofilm forming bacteria.

8. Disrupting quorum sensing by molecules which prevent the interaction of cells with auto inducers.

Figure1: Summary of methods discussed in this review to deter formation of biofilms on the surface of orthopaedic implants.

\section{Discussion}

Biomaterial science is a very active and creative area of research which has allowed the successful use of biomaterials in the orthopaedic field for over a century. However, infectability of biomaterials remains a clinical concern as it is associated with extensive patient morbidity and high economic burden. As discussed in section 2 of this review paper, the current treatment for THA complicated by infection, operative debridement and perioperative antibiotic therapy, is based on a distinct lack of evidence. Consequently, infections associated with biomaterials remain a clinically relevant issue. In our economic analysis we calculated an economic burden of $£ 7,000,000$ for the NHS, forecast to increase due to an ageing population.

As mentioned throughout this review, bacteria are able to adhere, colonise and develop into biofilms on the surface of biomaterials making infections associated with biomaterials physiologically different to other post- 
surgical infections. Unfortunately, biofilms express increased protection from the HID system and an increased resistance to antibiotic therapy in comparison to their planktonic counterparts ${ }^{8-10}$. Various resistive mechanisms of biofilms to antibiotics (Table 3) have been proposed. Understanding these mechanisms as well as biofilm formation and disruption is key to develop new preventive methods to complement classical antibiotic therapy. These methods focus on local delivery of antimicrobial compounds from the implant or cavity filling material and can be internal, if the implant surface or bulk material are concerned, or external if they are not directly related to the implant. Regarding internal methods, several strategies are under investigation, although superficial surface coatings are being the focus of extensive research ${ }^{112-155}$. A variety of antimicrobial compounds are used in coatings, from antibiotics to metals, and some studies show encouraging results. Some external methods also look promising ${ }^{156-166}$. However, the use of antibiotics is controversial due to developing resistance.

We believe that future research in this area should involve the creativity and diversity of biomaterials science to develop "smart" implant surfaces that selectively bind host cells, necessary for implant fixation, while discourage bacterial attachment. Perhaps this is not possible by only using implant surface modification and thus some external help from injectable biomaterials, i.e. hydrogels or cements, loaded with antimicrobial agents, preferably not antibiotics to avoid developing bacterial resistance, is the final piece to the puzzle of preventing infections associated with biomaterials. Therefore, research into alternative antimicrobial agents to antibiotics should go parallel to the research of new biomaterials as "smart" implants. This will only be possible by unravelling and understanding the molecular and cellular mechanisms behind formation and disruption of biofilms.

\section{Disclosure}

The authors have no conflicts of interest to declare.

\section{Acknowledgement}

This work was supported by the Restoration of Appearance and Function Trust (UK, registered charity number 299811) charitable funds. 


\section{References}

1. Luhr HG. The development of modern osteosynthesis. Mund Kiefer Gesichtschir. 2000;4 Suppl 1:S84-90.

2. Charnley J. Total hip replacement by low-friction arthroplasty. Clin Orthop Relat Res. 1970;72:7-21.

3. Charnley J, Eftekhar N. Postoperative infection in total prosthetic replacement arthroplasty of the hip-joint. With special reference to the bacterial content of the air of the operating room. British J Surg. 1969;56(9):641-9

4. Zajonz D, Wuthe L, Tiepolt S, Brandmeier P, Prietzel T, von Salis-Soglio GF, et al. Diagnostic work-up strategy for periprosthetic joint infections after total hip and knee arthroplasty: a 12-year experience on 320 consecutive cases. Patient Saf Surg. 2015;9:20.

5. Lindsay W, Bigsby E, Bannister G. Prevention of infection in orthopaedic joint replacement. J Perioper Pract. 2011;21(6):206-9.

6. Jafari SM, Coyle C, Mortazavi SMJ, Sharkley PF, Parvizi J. Revision hip arthroplasty: infection is the most common cause of failure. Clin Orthop Relat Res. 2010;468:2046-2051.

7. Wall D. Kin Recognition in Bacteria. Annu Rev Microbiol. 2016 Jun 17. [Epub ahead of print].

8. Contreras JJ, Sepúlveda M. The molecular basis of infections associated to orthopaedic implants. Rev Chilena Infectol. 2014;31(3):309-22.

9. Hobley L, Harkins C, MacPhee CE, Stanley-Wall NR. Giving structure to the biofilm matrix: an overview of individual strategies and emerging common themes. FEMS Microbiol Rev. 2015;39(5):649-69.

10. Lewis K. Multidrug tolerance of biofilms and persister cells. Curr Top Microbiol Immunol. 2008;322:10731.

11. Moyad TF, Thornhill T, Estok D. Evaluation and management of the infected total hip and knee. Orthopedics. 2008;31(6):581-8.

12. Seng P, Vernier M, Gay A, Pinelli PO, Legré R, Stein A. Clinical features and outcome of bone and joint infections with streptococcal involvement: 5-year experience of interregional reference centres in the south of France. New Microbes New Infect. 2016;12:8-17.

13. Sanderson PJ. Preventing infection in orthopedic implants. J Antimicrob Chemother. 1989;24(3):277-80.

14. Charnley J. Management of infected cases. Acrylic cement in orthopaedic surgery. Baltimore: Williams and Wilkins; 1970. p. 115-8.

15. Goulet JA, Pellicci PM, Brause BD, Salvati EM. Prolonged suppression of infection in total hip arthroplasty. J Arthroplasty. 1988;3(2):109-16. 
16. Aslam S. Effect of antibacterials on biofilms. Am J Infect Control. 2008;36(10):S175.e9-S.e11.

17. McDonald DJ, Fitzgerald RH, Jr., Ilstrup DM. Two-stage reconstruction of a total hip arthroplasty because of infection. J Bone Joint Surg Am. 1989;71(6):828-34.

18. Dieckmann R, Schulz D, Gosheger G, Becker K, Daniilidis K, Streitbürger A, Hardes J, Hoell S. Twostage hip revision arthroplasty with a hexagonal modular cementless stem in cases of periprosthetic infection. BMC Musculoskelet Disord. 2014;15:398.

19. Garvin KL, Evans BG, Salvati EA, Brause BD. Palaces gentamicin for the treatment of deep periprosthetic hip infections. Clin Orthop Relat Res. 1994(298):97-105.

20. Garvin KL, Hanssen AD. Current concepts review infection after total hip arthroplasty. Past, present and future. J Bone Joint Surg Am. 1995;21(6):206-9.

21. Gustilo RB, Tsukayama D. Treatment of infected cemented total hip arthroplasty with tobramycin beads and delayed revision with a cementless prosthesis and bone grafting. Orthopaedic Transactions. 1988;12:739.

22. Osmon DR, Berbari EF, Berendt AR, Lew D, Zimmerli W, Steckelberg JM, et al. Diagnosis and Management of Prosthetic Joint Infection: Clinical Practice Guidelines by the Infectious Diseases Society of America. Clinical Infectious Diseases. 2013;56(1):1-10.

23. Hughes PW, Salvati EA, Wilson PD, Blumenfeld EL. Treatment of sub-acute sepsis of the hip by antibiotics and joint replacement criteria for diagnosis with evaluation of 26 cases. Clin Orthop Relat Res. 1979(141):143-57.

24. Wolf M, Clar H, Friesenbichler J, Schwantzer G, Bernhardt G, Gruber G, et al. Prosthetic joint infection following total hip replacement: results of one-stage versus two-stage exchange. International orthopaedics. 2014;38(7):1363-8.

25. Beswick AD, Elvers KT, Smith AJ, Gooberman-Hill R, Lovering A, Blom AW. What is the evidence base to guide surgical treatment of infected hip prostheses? Systematic review of longitudinal studies in unselected patients. BMC Medicine. 2012;10.

26. Leonard HA, Liddle AD, Burke O, Murray DW, Pandit H. Single- or two-stage revision for infected total hip arthroplasty? A systematic review of the literature. Clin Orthop Relat Res. 2014;472(3):1036-42.

27. Wolf CF, Gu NY, Doctor JN, Manner PA, Leopold SS. Comparison of one and two-stage revision of total hip arthroplasty complicated by infection: a Markov expected-utility decision analysis. J Bone Joint Surg Am. 2011;93(7):631-9. 
28. Borroff M, Green M, Gregg PP, MacGregor PA, Porter MM, Tucker MK, et al. National Joint Registry 11th Annual Report 2014.

29. Kempthorne JT, Ailabouni R, Raniga S, Hammer D, Hooper G. Occult infection in aseptic joint loosening and the diagnostic role of implant sonication. Biomed Res Int. 2015;2015:946215.

30. Kandala NB, Connock M, Pulikottil-Jacob R, Sutcliffe P, Crowther MJ, Grove A, et al. Setting benchmark revision rates for total hip replacement: analysis of registry evidence. BMJ. 2015;350:h756.

31. Coello R, Charlett A, Wilson J, Ward V, Pearson A, Borriello P. Adverse impact of surgical site infections in English hospitals. Journal of Hospital Infection. 2005;60(2):93-103.

32. Klouche S, Sariali E, Mamoudy P. Total hip arthroplasty revision due to infection: A cost analysis approach. Orthopaedics \& Traumatology-Surgery \& Research. 2010;96(2):124-32.

33. Trampuz A, Widmer AF. Infections associated with orthopedic implants. Curr Opin Infect Dis. 2006;19(4):349-56.

34. Office for National Statistics. Population Ageing in the United Kingdom, its Constituent Countries and the European Union. 02 March 2012. http://www.ons.gov.uk/ons/dcp171776_258607.pdf

35. www.cdc.gov/nchs/data/nhds/4procedures/2010pro4_numberprocedureage.pdf

36. Kurtz S, Ong K, Lau E, Mowat F, Halpern M. Projections of primary and revision hip and knee arthroplasty in the United States from 2005 to 2030. J Bone Joint Surg Am. 2007;89(4):780-785.

37. Elek S. Experimental Staphylococcal Infections in the Skin of Man. Annals of the New York Academy of Sciences. 1956;65(3):85-90.

38. Gristina AG. Implant failure and the immuno-incompetent fibro-inflammatory zone. Clin Orthop Relat Res. 1994(298):106-18.

39. Elgohari S, Mihalkova M, Wloch C, Saei A, Harris R, Charlett A, et al. Surveillance of surgical site infections in NHS hospitals in England, 2013/14. London: 2014.

40. Kubacka A, Diez MS, Rojo D, Bargiela R, Ciordia S, Zapico I, Albar JP, Barbas C, Martins dos Santos VA, Fernández-García M, Ferrer M. Understanding the antimicrobial mechanism of $\mathrm{TiO}_{2}$-based nanocomposite films in a pathogenic bacterium. Sci Rep. 2014;4:4134.

41. Eltorai AE, Haglin J, Perera S, Brea BA, Ruttiman R, Garcia DR, Born CT, Daniels AH. Antimicrobial technology in orthopedic and spinal implants. World J Orthop. 2016;7(6):361-9. 
42. Vuong C, Kocianova S, Voyich JM, Yao YF, Fischer ER, DeLeo FR, et al. A crucial role for exopolysaccharide modification in bacterial biofilm formation, immune evasion, and virulence. Journal of Biological Chemistry. 2004;279(52):54881-6.

43. Montanaro L, Costerton JW, Arciola CR. Biofilm in implant infections: its production and regulation. The International Journal of Artificial Organs. 2005;28(11):1062-8.

44. Beech IB, Sunner JA, Arciola CR, Cristiani P. Microbially-influenced corrosion: Damage to prostheses, delight for bacteria. International Journal of Artificial Organs. 2006;29(4):443-52.

45. Gómez S, Vlad MD, López J, Fernández E. Design and Properties of 3D Scaffolds for Bone Tissue Engineering. Acta Biomater. 2016. pii: S1742-7061(16)30309-9.

46. García-Gareta E, Hua J, Blunn GW. Osseointegration of acellular and cellularised osteoconductive scaffolds: Is tissue engineering using mesenchymal stem cells necessary for implant fixation? J Biomed Mater Res Part A. 2015;103(3):1067-76.

47. Jeys LM, Grimer RJ, Carter SR, Tillman RM. Periprosthetic infection in patients treated for an orthopaedic oncological condition. J Bone Joint Surg Am. 2005;87(4):842-9.

48. Prieto HA, Berbari EF, Sierra RJ. Acute delayed infection: increased risk in failed metal on metal total hip arthroplasty. J Arthroplasty. 2014;29(9):1808-12.

49. Wyles CC, Van Demark RE $3^{\text {rd }}$, Sierra RJ, Trousdale RT. High rate of infection after aseptic revision of failed metal-on-metal total hip arthroplasty. Clin Orthop Relat Res. 2014;472(2):509-16.

50. Connaughton A, Childs A, Dylewski S, Sabesan VJ. Biofilm disrupting technology for orthopaedic implants: what's on the horizon? Front Med (Lausanne). 2014;1:22.

51. Choi S, Yang Y, Chae J. Surface plasmon resonance protein sensor using Vroman effect. Biosens Bioelectron. 2008;24(4):899-905.

52. Hirsh SL, McKenzie DR, Nosworthy NJ, Denman JA, Sezerman OU, Milek MMM. The Vroman effect: competitive protein exchange with dynamic multilayer protein aggregates. Colloids and Surfaces B: Biointerfaces. 2013;103:395-404.

53. Szczuka E, Urbańska K, Pietryka M, Kaznowski A. Biofilm density and detection of biofilm-producing genes in methicillin-resistant Staphylococcus aureus strains. Folia Microbiol (Praha). 2013;58(1):47-52.

54. Fisher JF, Mobashery S. Host-Guest Chemistry of the Peptidoglycan. J Med Chem. 2010;53(13):4813-29.

55. Davies DG, Geesey GG. Regulation of the alginate biosynthesis gene ALGC in pseudomonas-aeruginosa during biofilm development in continuous-culture. Appl Environ Microbiol. 1995;61(3):860-7. 
56. Foster TJ, Geoghegan JA, Ganesh VK, Höök M. Adhesion, invasion and evasion: the many functions of the surface proteins of Staphylococcus aureus. Nat Rev Microbiol. 2014;12(1):49-62.

57. Day CJ, Tran EN, Semchenko EA, Tram G, Hartley-Tassell LE, Ng PS, King RM, Ulanovsky R, McAtamney S, Apicella MA, Tiralongo J, Morona R, Korolik V, Jennings MP. Glycan:glycan interactions: High affinity biomolecular interactions that can mediate binding of pathogenic bacteria to host cells. Proc Natl Acad Sci U S A. 2015;112(52):E7266-75.

58. Limoli DH, Jones CJ, Wozniak DJ. Bacterial extracellular polysaccharides in biofilm formation and function. Microbiol Spectrum. 2014;3(3):MB-0011-2014.

59. Haiko J, Westerlund-Wikström B. The role of the bacterial flagellum in adhesion and virulence. Biology (Basel). 2013;2(4):1242-67.

60. Armbruster CR, Wolter DJ, Mishra M, Hayden HS, Radey MC, Merrihew G, MacCoss MJ, Burns J, Wozniak DJ, Parsek MR, Hoffman LR. Staphylococcus aureus Protein A Mediates Interspecies Interactions at the Cell Surface of Pseudomonas aeruginosa. MBio. 2016;7(3). pii: e00538-16.

61. Zhou G, Shi QS, Huang XM, Xie XB. The three bacterial lines of defense against antimicrobial agents. Int J Mol Sci. 2015;16(9):21711-33.

62. Zobell CE, Allen EC. The significance of marine bacteria in the fouling of submerged surfaces. J Bacteriol. 1935;29:239-51.

63. Branda SS, Vik S, Friedman L et al. Biofilms: the matrix revisited. Trends Microbiol. 2005;13:20-6.

64. Flemming HC, Wingender J. The biofilm matrix. Nat Rev Microbiol. 2010;8:623-33.

65. Arciola CR, Campoccia D, Ravaioli S, Montanaro L. Polysaccharide intercellular adhesin in biofilm: structural and regulatory aspects. Front Cell Infect Microbiol. 2015;5:7.

66. Van Acker H, Van Dijck P, Coenye T. Molecular mechanisms of antimicrobial tolerance and resistance in bacterial and fungal biofilms. Trends Microbiol. 2014;22(6):326-33.

67. Barnhart MM, Chapman MR. Curli biogenesis and function. Ann Rev Microbiol. 2006;60:131-47.

68. Branda SS, Chu F, Kearns DB, Losick R, Kolter R. A major protein component of the Bacillus subtilis biofilm matrix. Mol Microbiol. 2006;59:1229-38.

69. Borlee BR, Goldman AD, Murakami K, Samudrala R, Wozniak DJ, Parsek MR. Pseudomonas aeruginosa uses a cyclic-di-GMP-regulated adhesin to reinforce the biofilm extracellular matrix. Mol Microbiol. 2010;75:827-42. 
70. Olsen A, Jonsson A, Normark S. Fibronectin binding mediated by a novel class of surface organelles on Escherichia coli. Nature. 1989;338:652-5.

71. Sjobring U, Pohl G, Olsen A. Plasminogen, absorbed by Escherichia coli expressing curli or by Salmonella enteritidis exressing thin aggregative fimbriae, can be activated by simultaneously captured tissue-type plasminogen activator (t-PA). Mol Microbiol. 1994;14:443-52.

72. Ben Nasr A, Olsen A, Sjobring U, Muller-Sterl W, Bjorck L. Assembly of human contact phase proteins and release of brandykinin at the surface of curli-expressing Escherichia coli. Mol Microbiol. 1996;20:92735.

73. Gualdi L, Tagliabue L, Bertagnoli S, Ierano T, De Castro C, Landini P. Cellulose modulates biofilm formation by counteracting curli-mediated collonization of solid surfaces in Escherichia coli. Microbiol. 2008;154:2017-24.

74. Kobayashi K, Iwano M. BslA (YuaB) forms a hydrophbic layer on the surface of Bacillus subtilis biofilms. Mol Microbiol. 2012;85:51-66.

75. Hobley L, Ostrowski A, Rao FV, et al. BslA is a self-assembling bacterial hydrophobin that coats the Bacillus subtilis biofilm. P Natl Acad Sci USA. 2013;110:13600-5.

76. Otto M. Staphylococcal infections: mechanisms of biofilm maturation and detachment as critical determinants of pathogenicity. Ann Rev Med. 2013;64:175-188.

77. Periasamy S, Joo HS, Duong AC, Bach TH, Tan VY, Chatterjee SS, et al. How Staphylococcus aureus biofilms develop their characteristic structure. Proc Natl Acad Sci USA. 2012;109:1281-86.

78. Wang R, Khan BA, Cheung GY, Bach TH, Jameson-Lee M, Kong KF, et al. Staphylococcus epidermidis surfactant peptides promote biofilm maturation and dissemination of biofilm-associated infection in mice. J Clin Invest. 2011;121:238-48.

79. Ganesan M, Stewart EJ, Szafranski J, Satorius AE, Younger JG, Solomon MJ. Molar mass, entanglement, and associations of the biofilm polysaccharide of Staphylococcus epidermidis. Biomacromolecules. 2013;14(5):1474-81.

80. Sauer K, Camper AK, Ehrlich GD, Costerton JW, Davies DG. Pseudomonas aeruginosa displays multiple phenotypes during development as a biofilm. J Bacteriol. 2002;184(4):1140-54.

81. Nickel JC, Ruseska I, Wright JB, Costerton JW. Tobramycin resistance of pseudomonas-aeruginosa cells growing as a biofilm on urinary catheter material. Antimicrob Agents Chemother. 1985;27(4):619-24. 
82. Suci PA, Mittelman MW, Yu FP, Geesey GG. Investigation of Ciprofloxacin Penetration Into Pseudomonas Aeruginosa Biofilms. Antimicrob Agents Chemother. 1994;38(9):2125-33.

83. Hoyle BD, Alcantara J, Costerton JW. Pseudomonas aeruginosa biofilm as a diffusion barrier to piperacillin. Antimicrob Agents Chemother. 1992;36(9):2054-6.

84. Sanchez-Vizuete P, Orgaz B, Aymerich S, Le Coq D, Briandet R. Pathogens protection against the action of disinfectants in multispecies biofilms. Front Microbiol. 2015;6:705.

85. Slack MPE, Nichols WW, Dorrington SM, Walmsley HL. Inhibition of tobramycin diffusion by binding to alginate. Antimicrob Agents Chemother. 1988;32(4):518-23.

86. Lamppa JW, Griswold KE. Alginate lyase exhibits catalysis-independent biofilm dispersion and antibiotic synergy. Antimicrob Agents Chemother. 2013;57(1):137-45.

87. Dunne WM, Mason EO, Kaplan SL. Diffusion of rifampin and vancomycin through a Staphylococcus epidermidis biofilm. Antimicrob Agents Chemother. 1993;37(12):2522-6.

88. Stewart PS. A review of experimental measurements of effective diffusive permeabilities and effective diffusion coefficients in biofilms. Biotechnol Bioeng. 1998;59(3):261-72.

89. Peterson BW, He Y, Ren Y, Zerdoum A, Libera MR, Sharma PK, et al. Viscoelasticity of biofilms and their recalcitrance to mechanical and chemical challenges. FEMS Microbiol Rev. 2015;39(2):234-45.

90. Stewart PS, Franklin MJ, Williamson KS, Folsom JP, Boegli L, James GA. Contribution of stress responses to antibiotic tolerance in Pseudomonas aeruginosa biofilms. Antimicrob Agents Chemother. 2015;59(7):3838-47.

91. Wentland EJ, Stewart PS, Huang CT, McFeters GA. Spatial variations in growth rate within Klebsiella pneumoniae colonies and biofilm. Biotechnology Progress. 1996;12(3):316-21.

92. Brown MR, Allison DG, Gilbert P. Resistance of bacterial biofilms to antibiotics: a growth-rate related effect? J Antimicrob Chemother. 1988;22(6):777-80.

93. Tuomanen E, Cozens R, Tosch W, Zak O, Tomasz A. The rate of killing of escherichia-coli by beta-lactam antibiotis is strictly proportional to the rate of bacterial growth. J Gen Microbiol. 1986;132:1297-304.

94. Huang CT, Yu FP, McFeters GA, Stewart PS. Nonuniform Spatial Patterns Of Respiratory Acitivty Within Biofilms During Disinfection. Appl Environ Microbiol. 1995;61(6):2252-6.

95. Korber DR, James GA, Costerton JW. Evaluation of Fleroxacin Activity Against Established Pseudomonas-Fluorescens Biofilms. Appl Environ Microbiol. 1994;60(5):1663-9. 
96. Shirtliff ME, Peters BM, Jabra-Rizk MA. Cross-kingdom interactions: Candida albicans and bacteria. FEMS Microbiol Lett. 2009;299(1):1-8.

97. Harriott MM, Noverr MC. Candida albicans and Staphylococcus aureus Form Polymicrobial Biofilms: Effects on Antimicrobial Resistance. Antimicrob Agents Chemother. 2009;53(9):3914-22.

98. Pammi M, Liang R, Hicks J, Mistretta TA, Versalovic J. Biofilm extracellular DNA enhances mixed species biofilms of Staphylococcus epidermidis and Candida albicans. BMC Microbiol. 2013;13:257.

99. Campoccia D, Montanaro L, Arciola CR. The significance of infection related to orthopedic devices and issues of antibiotic resistance. Biomaterials. 2006;27(11):2331-9.

100. De Beer D, Stoodley P, Roe F, Lewandowski Z. Effects of Biofilm Structures On Oxygen Distribution and Mass-Transport. Biotechnol Bioeng. 1994;43(11):1131-8.

101. Zhang TC, Bishop PL. Evaluation of substrate and pH effects in a nitrifying biofilm. Water Environ Res. 1996;68(7):1107-15.

102. Bryant RE, Fox K, Oh G, Morthland VH. Beta-lactam enhancement of aminoglycoside activity under conditions of reduced $\mathrm{pH}$ and oxygen tension that may exist in infected tissues. $\mathrm{J}$ Infect Dis. $1992 ; 165(4): 676-82$.

103. Prigent-Combaret C, Vidal O, Dorel C, Lejeune P. Abiotic surface sensing and biofilm-dependent regulation of gene expression in Escherichia coli. J Bacteriol. 1999;181(19):5993-6002.

104. Lewis K. Persister cells, dormancy and infectious disease. Nature Reviews Microbiol. 2007;5(1):48-56.

105. Cochran WL, McFeters GA, Stewart PS. Reduced susceptibility of thin Pseudomonas aeruginosa biofilms to hydrogen peroxide and monochloramine. J Appl Microbiol. 2000;88(1):22-30.

106. Hausner M, Wuertz S. High rates of conjugation in bacterial biofilms as determined by quantitative in situ analysis. Appl Environ Microbiol. 1999;65(8):3710-3.

107. Drake DR, Paul J, Keller JC. Primary bacterial colonization of implant surfaces. Int J Oral Maxillofac Implants 1999;14(2):226-32.

108. Chimutengwende-Gordon M, Pendegrass C, Blunn G. Enhancing the soft tissue seal around intraosseous transcutaneous amputation prostheses using silanized fibronectin titanium alloy. Biomed Mater. 2011;6(2).

109. Montanaro L, Campoccia D, Arciola CR. Advancements in molecular epidemiology of implant infections and future perspectives. Biomaterials. 2007;28(34):5155-68. 
110. Vasilev K, Cook J, Griesser HJ. Antibacterial surfaces for biomedical devices. Expert Rev Med Devices. 2009;6(5):553-67.

111. Veerachamy S, Yarlagadda T, Manivasagram G, Yarlagadda PK. Bacterial adherence and biofilm formation of medical implants: a review. Proc Inst Mech Eng H. 2014;228(10):1083-99.

112. Boyd RD, Verran J, Jones MV, Bhakoo M. Use of the atomic force microscope to determine the effect of substratum surface topography on bacterial adhesion. Langmuir. 2002;18(6):2343-6.

113. Koseki H, Yonekura A, Shida T, Yoda I, Horiuchi H, Morinaga Y, et al. Early staphylococcal biofilm formation on solid orthopaedic implant materials: in vitro study. PLoS One. 2014;9(10):e107588

114. Junter GA, Thébault P, Lebrun L. Polysaccharide-based antibiofilm surfaces. Acta Biomater. 2016;30:1325.

115. Liu C, Zhao Q, Liu Y, Wang S, Abel EW. Reduction of bacterial adhesion on modified DLC coatings. Colloids Surf B Biointerfaces. 2008;61(2):182-7.

116. Bruellhoff K, Fiedler J, Möller M, Groll J, Brenner RE. Surface coating strategies fo prevent biofilm formation on implant surfaces. Int J Artif Organs. 2010;33(9):646-53.

117. Rabea EI, Badawy MET, Stevens CV, Smagghe G, Steurbaut W. Chitosan as antimicrobial agent: Applications and mode of action. Biomacromolecules. 2003;4(6):1457-65.

118. Raafat D, von Bargen K, Haas A, Sahl H-G. Insights into the mode of action of chitosan as an antibacterial compound. Appl Environ Microbiol. 2008;74(12):3764-73.

119. Kong M, Chen XG, Xing K, Park HJ. Antimicrobial properties of chitosan and mode of action: A state of the art review. Int J Food Microbiol. 2010;144(1):51-63.

120. Bumgardner J, Wiser R, Gerard P, Bergin P, Chestnutt B, Marin M, et al. Chitosan: potential use as a bioactive coating for orthopaedic and craniofacial/dental implants. J Biomater Sci Polymer edition. 2003;14(5):423-38.

121. Li LH, Li M, Li D, He P, Xia H, Zhang Y, Mao C. Chemical functionalization of bone implants with nanoparticle-stabilized chitosan and methotrexate for inhibiting both osteoclastoma formation and bacterial infection. J Mater Chem B Mater Biol Med. 2014;2(36):5952-61.

122. Greenfeld JI, Sampath L, Popilskis SJ, Brunnert SR, Stylianos S, Modak S. Decreased bacterial adherence and biofilm formation on chlorhexidine and silver sulfadiazine-impregnated central venous catheters implanted in swine. Critical Care Med. 1995;23(5):894-900.

123. Borkow G, Gabbay J. Copper as a Biocidal Tool. Current medicinal chemistry. 2005;12(18):2163-75. 
124. Hans M, Erbe A, Matthews S, Chen Y, Solioz M, Mücklich F. Role of copper oxides in contact killing of bacteria. Langmuir. 2013;29(52):16160-6.

125. Kim TN, Feng QL, Kim JO, Wu J, Wang H, Chen GQ, et al. Antimicrobial effects of metal ions (Ag+, Cu2+, Zn2+) in hydroxyapatite. J Mater Sci Mater Med. 1998;9(3):129-34.

126. Suska F, Emanuelsson L, Johansson A, Tengvall P, Thomsen P. Fibrous capsule formation around titanium and copper. J Biomed Mater Res Part A. 2008;85(4):888-96.

127. Hoene A, Prinz C, Walschus U, Lucke S, Patrzyk M, Wilhem L, Neumann HG, Schlosser M. In vivo evaluation of copper release and acute local tissue reactions after implantation of copper-coated titanium implants in rats. Biomed Mater. 2013;8(3):035009.

128. Grenho L, Salgado CL, Fernandes MH, Monteiro FJ, Ferraz MP. Antibacterial activity and biocompatibility of three-dimensional nanostructured porous granules of hydroxyapatite and zinc oxide nanoparticles-an in vitro and in vivo study. Nanotechnology. 2015;26(31):315101.

129. Li Y, Liu G, Zhai Z, Liu L, Li H, Yang K, et al. Antibacterial properties of magnesium in vitro and in an in vivo model of implant-associated methicillin-resistant Staphylococcus aureus infection. Antimicrob Agents Chemother. 2014;58(12):7586-91.

130. Li Y, Leung P, Yao L, Song QW, Newton E. Antimicrobial effect of surgical masks coated with nanoparticles. J Hospital Infection. 2006;62(1):58-63.

131. Lorente L. Antimicrobial-impregnated catheters for the prevention of catheter-related bloodstream infections. World J Crit Care Med. 2016;5(2):137-42.

132. Ostlie DJ, Juang D, Aguayo P, Pettiford-Cunningham JP, Erkmann EA, Rash DE, Sharp SW, Sharp RJ, St Peter SD. Topical silver sulfadiazine vs collagenase ointment for the treatment of partial thickness burns in children: a prospective randomized trial. J Pediatr Surg. 2012;47(6):1204-7.

133. Zhou K, Krug K, Stachura J, Niewczyk P, Ross M, Tutuska J, Ford G. Silver-Collagen Dressing and Highvoltage, Pulsed-current Therapy for the Treatment of Chronic Full-thickness Wounds: A Case Series. Ostomy Wound Manage. 2016;62(3):36-44.

134. Gilbert RE, Harden M. Effectiveness of impregnated central venous catheters for catheter related blood stream infection: a systematic review. Curr Opin Infect Dis. 2008;21(3):235-45.

135. Atiyeh BS, Costagliola M, Hayek SN, Dibo SA. Effect of silver on burn wound infection control and healing: Review of the literature. Burns. 2007;33(2):139-48. 
136. Wilkinson LJ, White RJ, Chipman JK. Silver and nanoparticles of silver in wound dressings: a review of efficacy and safety. J Wound Care. 2011;20(11):543-9.

137. Martinez-Gutierrez F, Boegli L, Agostinho A, Sanchez EM, Bach H, Ruiz F, et al. Anti-biofilm activity of silver nanoparticles against different microorganisms. Biofouling. 2013;29(6):651-60.

138. Stine AE, Nassar D, Miller JK, Clemons CB, Wilber JP, Young GW, et al. Modeling the response of a biofilm to silver-based antimicrobial. Mathematical Biosci. 2013;244(1):29-39.

139. Palanisamy NK, Ferina N, Amirulhusni AN, Mohd-Zain Z, Hussaini J, Ping LJ, et al. Antibiofilm properties of chemically synthesized silver nanoparticles found against Pseudomonas aeruginosa. J Nanobiotechnology. 2014;12:7.

140. Brennan SA, Ní Fhoghlú C, Devitt BM, O’Mahony FJ, Brabazon D, Walsh A. Silver nanoparticles and their orthopaedic applications. J Orthop Res. 2015. Doi:10.1002/jor.22910. Ahead of print.

141. Actis L, Srinivasan A, Lopez-Ribot JL, Ramasubramanian AK, Ong JL. Effect of silver nanoparticle geometry on methicillin susceptible and resistant Staphylococcus aureus, and osteoblast viability. J Mater Sci Mater Med. 2015;26(7):5538.

142. Tran N, Kelley MN, Tran PA, Garcia DR, Jarrell JD, Hayda RA, Born CT. Silver doped titanium oxidePDMS hybrid coating inhibits Staphylococcus aureus and Staphylocuccus epidermidis growth on PEEK. Mater Sci Eng C Mater Biol Appl. 2015;49:201-9.

143. Gosheger G, Hardes J, Ahrens H, Streitburger A, Buerger H, Erren M, et al. Silver-coated megaendoprostheses in a rabbit model: An analysis of the infection rate and toxicological side effects. Biomaterials. 2004;25(24): 5547-56.

144. Coester LM, Nepola JV, Allen J, Marsh JL. The effects of silver coated external fixation pins. Iowa Orthop J. 2006;26:48-53.

145. Shimazaki T, Miyamoto H, Ando Y, Noda I, Yonekura Y, Kawano S, et al. In vivo antibacterial and silverreleasing properties of novel thermal sprayed silver-containing hydroxyapatite coating. J Biomed Mater Res B Appl Biomater. 2010;92:386-9.

146. Hobman JL, Crossman L. Bacterial antimicrobial metal ion resistance. J Med Microbiol. 2015;64(Pt 5):471-97.

147. Wafa H, Grimer RJ, Reddy K, Jeys L, Abudu A, Carter SR. Tillman RM. Retrospective evaluation of the incidence of early periprosthetic infection with silver-treated endoprostheses in high-risk patients: casecontrol study. Bone Joint J. 2015;97-B(2):252-7. 
148. Sathishkumar M, Mahadevan A, Pavagadhi S, Kaushik R, Sharma VK, Balasubramanian R. Biological Synthesis of Silver Nanoparticles and Assessment of Their Bactericidal Activity. In: Shamim N, Sharma VK, editors. Sustainable Nanotechnology and the Environment: Advances and Achievements. ACS Symposium Series. 1124. Washington: Amer Chemical Soc; 2013. p. 107-20.

149. Jose B, Antoci V Jr, Zeiger AR, Wickstrom E, Hickok NJ. Vancomycin covalently bonded to titanium beads kills Staphylococcus aureus. Chem Biol. 2005;12(9):1041-1048.

150. Antoci V Jr, King SB, Jose B, Parvizi J, Zeiger AR, Wickstrom E, et al. Vancomycin covalently bonded to titanium alloy prevents bacterial colonization. J Orthop Res. 2007;25(7) 858-866.

151. Stigter M, Bezemer J, de Groot K, Layrolle P. Incorporation of different antibiotics into carbonated hydroxyapatite coatings on titanium implants, release and antibiotic efficacy. J Control Release. 2004;99(1):127-37.

152. Stigter M, de Groot K, Layrolle P. Incorporation of tobramycin into biomimetic hydroxyapatite coating on titanium. Biomaterials. 2002;23(20):4143-53.

153. Tian B, Tang S, Wang CD, Wang WG, Wu CL, Guo YJ, et al. Bactericidal properties and biocompatibility of a gentamicin-loaded Fe3O4/carbonated hydroxyapatite coating. Colloids Surf B Biointerfaces. 2014;123:403-12.

154. Jennings JA, Carpenter DP, Troxel KS, Beenken KE, Smeltzer MS, Courtney HS, Haggard WO. Novel antibiotic-loaded point-of-care implant coating inhibits biofilm. Clin Orthop Relat Res. 2015;473(7):227082.

155. Kumeria T, Mon H, Aw MS, Gulati K, Santos A, Griesser HJ, Losic D. Advanced biopolymer-coated drug-releasing titania nanotubes (TNTs) implants with simultaneously enhanced osteblast adhesion and antibacterial properties. Colloids Surf B Biointerfaces. 2015;130:255-63.

156. Engesaeter LB, Lie SA, Espehaug B, Furnes O, Vollset SE, Havelin LI. Antibiotic prophylaxis in total hip arthroplasty - Effects of antibiotic prophylaxis systemically and in bone cement on the revision rate of 22,170 primary hip replacements followed 0-14 years in the Norwegian Arthroplasty Register. Acta Orthopaedica Scandinavica. 2003;74(6):644-51.

157. Marks KE, Nelson CL, Lautenschlager EP. Antibiotic-impregnated acrylic bone cement. J Bone Joint Surg Am. 1976;58(3):358-64.

158. Moran JM, Greenwald AS, Matejczyk MB. Effect of gentamicin on shear and interface strengths of bonecement. Clin Orthop Relat Res. 1979(141):96-101. 
159. Slane J, Vivanco J, Rose W, Ploeg HL, Squire M. Mechanical, material, and antimicrobial properties of acrylic bone cement impregnated with silver nanoparticles. Mater Sci Eng C Mater Biol Appl. 2015;48:188-46.

160. Overstreet D, McLaren A, Calara F, Vernon B, McLemore R. Local gentamicin delivery from resolrbable viscous hydrogels is therapeutically effective. Clin Orthop Relat Res. 2015;473(1):337-47.

161. Ter Boo GJ, Grijpma DW, Moriarty TF, Richards RG, Eglin D. Antimicrobial delivery systems for local infection prophylaxis in orthopedic and trauma surgery. Biomaterials. 2015;52:113-25.

162. Bezuidenhout MB, van Staden AD, Oosthuizen GA, Dimitrov DM, Dicks LM. Delivery of antibiotics from cementless titanium-alloy cubes may be a novel way to control postoperative infections. Biomed Res Int. 2015;2015:856859.

163. Maione D, Margarit I, Rinaudo CD, Masignani V, Mora M, Scarselli M, et al. Identification of a universal group B Streptococcus vaccine by multiple genome screen. Science. 2005;309(5731):148-50.

164. Fowler VG, Allen KB, Moreira ED, Moustafa M, Isgro F, Boucher HW, et al. Effect of an investigational vaccine for preventing Staphylococcus aureus infections after cardiothoracic surgery: A randomized trial. JAMA. 2013;309(13):1368-1378.

165. Brady RA, Leid JG, Kofonow J, Costerton JW, Shirtliff ME. Immunoglobulins to surface-associated biofilm immunogens provide a novel means of visualization of methicillin-resistant Staphylococcus aureus biofilms. Appl Environ Microbiol. 2007;73(20):6612-9.

166. Ruiz-Ruigomez M, Badiola J, Schmidt-Malan SM, Greenwood-Quaintance K, Karau MJ, Brinkman et al. Direct Electrical Current Reduces Bacterial and Yeast Biofilm Formation. Int J Bacteriol. 2016;2016:9727810. 